\title{
Power Quality Improvement Using D-STATCOM in Distribution System at Various Faults
}

\author{
M. Balasubba Reddy \\ Associate Professor, Department of EEE, S.V.College of Engineering, Tirupati, Andhra Pradesh, India
}

\begin{abstract}
As a promising renewable alternative, the wind power is one of the significant sources of generation. Reactive power compensation and harmonic reduction in a low voltage distribution networks for integration of wind power to the grid are the main issues addressed in this paper. This paper proposes a control scheme based on instaneous $\mathrm{Pq}$ theory for compensating the reactive power requirement of a three phase grid connected wind driven induction generator as well as the harmonics produced by the non linear load connected to the PCC using STATCOM. The proposed control scheme is simulated using MATLAB/SIMULINK. The Simulation results are presented in this paper.
\end{abstract}

KEYWORDS: wind power, distribution network, induction generator, STATCOM, reactive power.

\section{INTRODUCTION}

The integration of wind power to grid introduces power quality issues, which mainly consist of voltage regulation and reactive power compensation Induction machines are mostly used as generators in wind power based generations. Induction generators draw reactive power from the grid to which they are connected. Therefore, the integration of wind power to power system networks is one of the main concerns of the power system engineers. The addition of wind power into the electric grid affect's the power quality [I].During the last few years, power electronic technology plays an important role in distributed generation and integration of in denergy generation into the electric grid[2]. A non-linear load on a power system is typically a rectifier the square of the voltage. Consequently, the reactive power supplied from the capacitors decreases rapidly when the voltage decreases [3] .To overcomes the above disadvantages; STATCOM is best suited for reactive power compensation and harmonic reduction. It is based on a controllable voltage source converter the square of the voltage. Consequently, the reactive power supplied from the capacitors decreases rapidly when the voltage decreases [3] .To overcomes the above disadvantages; STATCOM is best suited for reactive power compensation and harmonic reduction. It is based on a controllable voltage source converter.

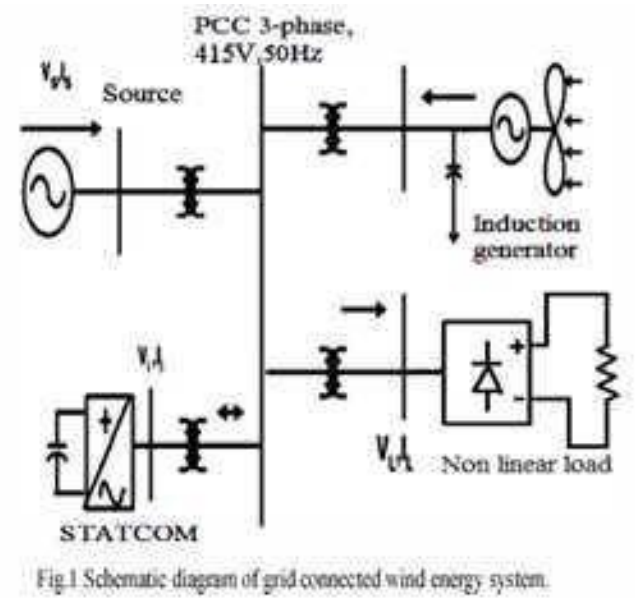

The proposed STATCOM control scheme for grid connected wind energy generation for power quality improvement has following objective. This paper is organized as follows. Section II discusses reactive power requirements of induction generator. Section III, IV and V discuss wind driven induction generator with STATCOM, reference current generation and hysteresis current controller for STATCOM respectively. 


\section{REFERENCE CURRENTGENERATION FOR STATCOM}

Reference current for the STATCOM is generated based on instantaneous reactive power theory [7]-[1O]. A STATCOM injects the compensation current which is a sum of reactive component current of IG, non-linear load and harmonic component current of non-linear load. Reference current for the STATCOM is generated based on instantaneous reactive power theory [7]-[1O]. A STATCOM injects the compensation current which is a sum of reactive component current of IG, non-linear load and harmonic component current of non-linear load. Reference current for the STATCOM is generated based on instantaneous reactive power theory [7]-[1O]. A STATCOM injects the compensation current which is a sum of reactive component current of IG, non-linear load and harmonic component current of non-linear load. Pq theory gives a generalized definition of instantaneous reactive power, which is valid for sinusoidal or non sinusoidal, balanced or unbalanced, three-phase power systems with or without zero sequence currents and/or voltages. Pq theory gives a generalized definition of instantaneous reactive power, which is valid for sinusoidal or non sinusoidal, balanced or unbalanced, three-phase power systems with or without zero sequence currents and/or voltages. Pq theory gives a generalized definition of instantaneous reactive power, which is valid for sinusoidal or non sinusoidal, balanced or unbalanced, three-phase power systems with or without zero sequence currents and/or voltages.

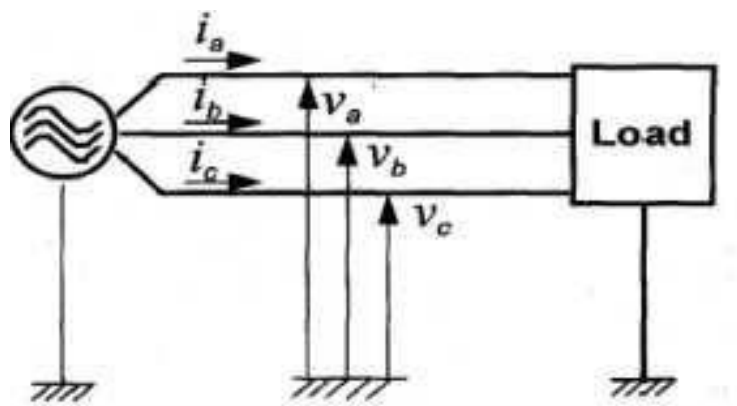

Figure.2.Three phase system

\section{SYSTEM MODELLING \& RESULTS}

The test system composes a $230 \mathrm{kV}, 50 \mathrm{~Hz}$ generation system, represented by a Thevenin equivalent, feeding into the primary side of a 3-winding transformer. A varying load is connected to the $11 \mathrm{kV}$, secondary side of the transformer. In the absence of DSTATCOM we can see the voltage sag due to the three phase fault introduced during different conditions. Here Simulation results are presented for four cases. In case one voltage sag without DSTATCOM at three phase fault, case two voltage sag with DSTATCOM at three phase fault, case three voltage swell without DSTATCOM by removing three phase load and in case four voltage swell with DSTATCOM by removing three phase load is considered

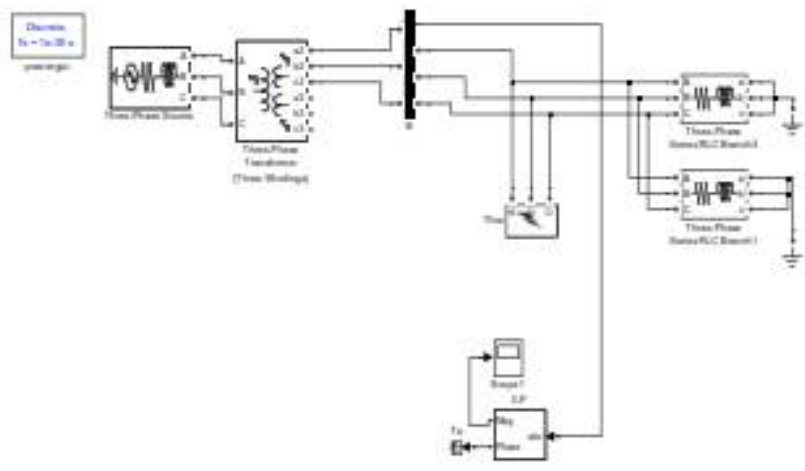

Figure.3 Test system for voltage Sag Without DSTATCOM. 
ISSN (Print) : 2320 - 3765

ISSN (Online): 2278 - 8875

International Journal of Advanced Research in Electrical, Electronics and Instrumentation Engineering

Vol. 2, Issue 1, January 2013

TABLE I

\begin{tabular}{|c|c|c|c|c|c|c|c|c|c|c|}
\hline \multirow{2}{*}{$\begin{array}{l}\text { Fault } \\
\text { resista } \\
\text { nce }\end{array}$} & \multicolumn{2}{|c|}{$3 \mathrm{P}$ fault } & \multicolumn{2}{|c|}{ L-G fault } & \multicolumn{2}{|c|}{ L-L fault } & \multicolumn{2}{|c|}{$2 \mathrm{~L}-\mathrm{G}$ fault } & \multicolumn{2}{|c|}{ 3P-G fault } \\
\hline & $\begin{array}{c}\text { With } \\
\text { D } \\
\text { STATCO } \\
\text { M }\end{array}$ & $\begin{array}{l}\text { Without } \\
\text { DSTAT } \\
\text { COM }\end{array}$ & $\begin{array}{l}\text { With } \\
\text { DST } \\
\text { ATC } \\
\text { OM }\end{array}$ & $\begin{array}{c}\text { Without } \\
\text { DSTATC } \\
\text { OM }\end{array}$ & $\begin{array}{c}\text { With } \\
\text { DSTATC } \\
\text { OM }\end{array}$ & $\begin{array}{l}\text { Without } \\
\text { DSTAT } \\
\text { COM }\end{array}$ & $\begin{array}{c}\text { With } \\
\text { DSTAT } \\
\text { COM }\end{array}$ & $\begin{array}{c}\text { Without } \\
\text { DSTATC } \\
\text { OM }\end{array}$ & $\begin{array}{l}\text { With } \\
\text { DSTAT } \\
\text { COM }\end{array}$ & $\begin{array}{c}\text { Without } \\
\text { DSTAT } \\
\text { COM }\end{array}$ \\
\hline 0.4 & 0.88 & 0.48 & 0.95 & 0.75 & 1.02 & 0.64 & 0.95 & 0.55 & 0.88 & 0.48 \\
\hline 0.6 & 0.92 & 0.62 & 0.98 & 0.81 & 1.01 & 0.73 & 0.98 & 0.68 & 0.92 & 0.62 \\
\hline 0.8 & 0.95 & 0.72 & 0.99 & 0.85 & 1.01 & 0.8 & 0.99 & 0.76 & 0.93 & 0.73 \\
\hline 1 & 0.98 & 0.8 & 0.99 & 0.88 & 1.01 & 0.85 & 0.99 & 0.82 & 0.98 & 0.8 \\
\hline
\end{tabular}

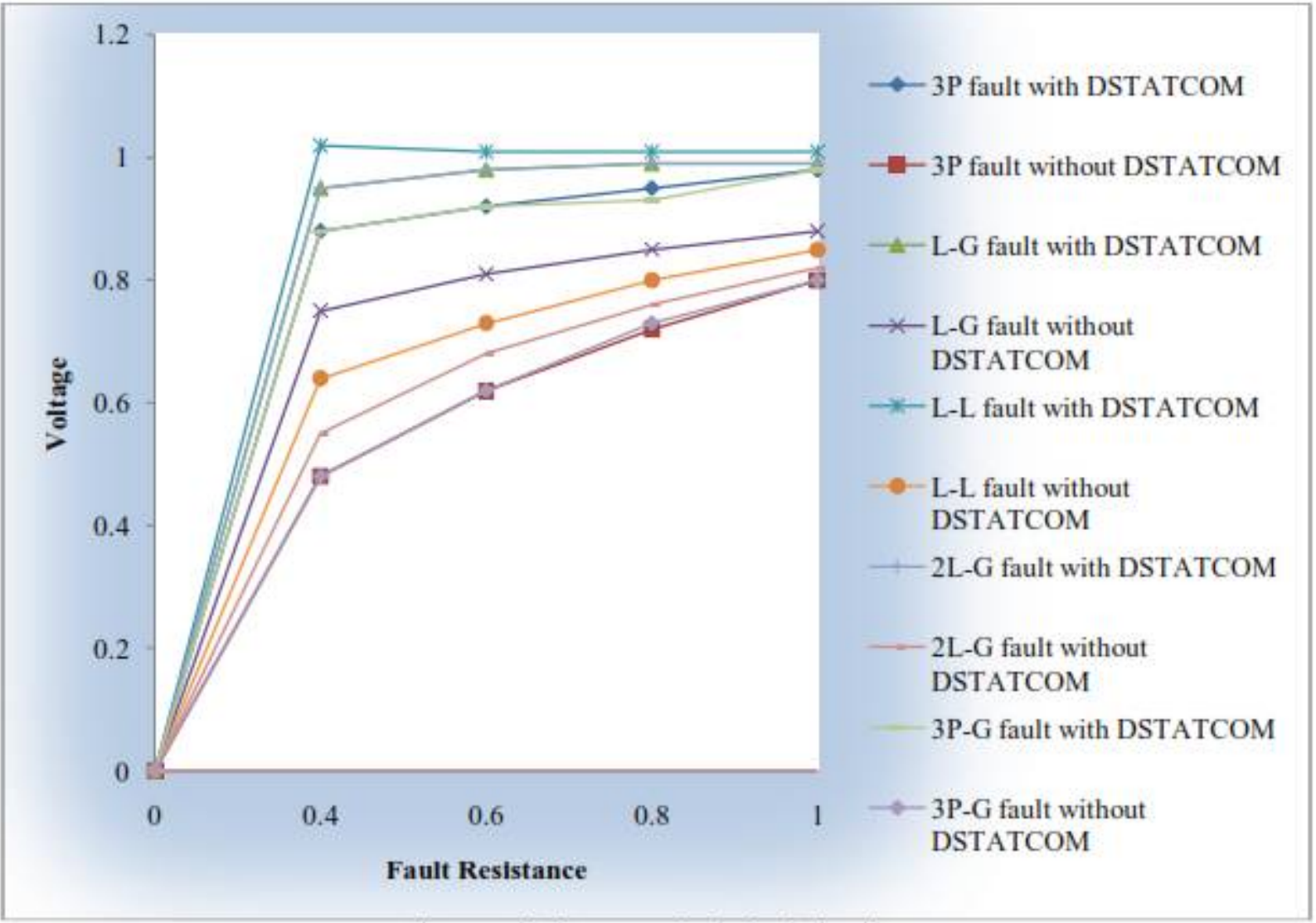

Figure.4.Graphical Representation for data in the table .

As shown in above graph, a very effective voltage regulation which is provided by the D-STATCOM can be clearly appreciated. The D-STATCOM eliminates the voltage sag \& swell. In spite of sudden fault and load variations, the regulated RMS voltage shows a reasonably smooth profile, where power quality of the system is improved upto 95$98 \%$ of the poor voltage.

\section{CONCLUSION}

This paper has presented the power quality problems such as voltage sags and swell. Compensation techniques of custom power electronic device D-ST ATCOM was presented. The design and applications of D-STATCOM for voltage sags, swells and comprehensive results were presented. The simulation results show that the voltage sags can be mitigate by inserting DSTATCOM caused due to faults \& swell due to sudden switching of loads in the distribution system. The Voltage Source Convert (VSC) was implemented with the help of Sinusoidal Pulse Width Modulation (SPWM). The control scheme was tested under a wide range of operating conditions, and it was observed to be very robust in every case. For modeling and simulation of a D-STATCOM by using the highly developed graphic facilities available in MATLAB/SIMULINK were used.

The simulations carried out here showed that the DSTATCOM provides relatively better voltage Regulation capabilities. 
ISSN (Print) : 2320 - 3765

ISSN (Online): $2278-8875$

International Journal of Advanced Research in Electrical, Electronics and Instrumentation Engineering

Vol. 2, Issue 1, January 2013

\section{REFERENCES}

[1] Anaya-Lara, E. Acha, "Modeling and analysis of custom power systems by PSCAD/EMTDC," IEEE Trans. Power Delivery, vol. 17, no I, pp. 266-272, January 2002.

[2] S. Ravi Kumar, S. Sivanagaraju, "Simualgion of D-STATCOM and DVR in power system," ARPN journal of engineering and applied science, vol. 2, no. 3, pp. 7-13, June 2007.

[3] H. Hingorani, "Introducing custom power", IEEE Spectrum, vol. 32, no 6, pp. 41-48, June 1995.

[4] N. Hingorani, "FACTS-Flexible ac transmission systems," in Proc. IEE 5th IntConf AC DCTransmission, London, U.K., 1991, Conf Pub. 345, pp. $1-7$.

[5] Mahesh Singh, VaibhavTiwari, "Modeling analysis and solution to power quality problems,"unpublished.

[6] G. Venkataramana, and BJohnson, "A pulse width modulated power line conditioner for sensitive load centers," IEEE Trans. Power Delivery, vol. 12, pp. 844-849, Apr. 1997.

[7] W. Freitas, A. Morelato, "Comparitive study between power system block set and PSCAD/EMTDC for transient analysis of custom power devices based on voltage source converter," PST, New Orleans, USA, 2003, pp. 1-6.

[8] El Shatshat, R., Kazerani, M and Salama, M M (2002), "Power quality improvement in 3-phase 3-wire distribution systems using modular active power filter" Electric Power Systems Research, Vol. 61, Issue 3, April 2002, pp 185-194.

[9] Sen Ouyang and Jianhua Wang (2007), “A new morphology method for enhancing power quality monitoring system" International Journal of Electrical Power \& Energy Systems, Vol. 29, Issue 2, February 2007, pp 121-128. 